\title{
Cavalaria e prática militar na fase inicial da Guerra dos Cem Anos
}

(1346-1356)

Ives Leocelso Silva Costal

Resumo: Este artigo pretende analisar as práticas militares do reinos da França e da Inglaterra durante a fase inicial da Guerra dos Cem Anos, destacando a atuação da Cavalaria, força montada de cunho aristocrático que veio a se tornar sinônimo da ordem senhorial. Para tanto foram escolhidos como marcos temporais as batalhas de Crécy (1346) e Poitiers (1356), confrontos excepcionais nos quais tropas inglesas de arqueiros e guerreiros a pé venceram os cavaleiros franceses. Norteando o trabalho encontra-se uma pergunta fundamental: por quê a Cavalaria francesa, mesmo diante do fracasso, não buscou se adaptar às realidades da guerra, à semelhança dos ingleses? O resultado é um estudo sobre os elementos políticos e sociais da guerra no medievo, bem como um exercício comparativo entre as formas de organização militar destes dois reinos.

Palavras-chave: Guerra dos Cem Anos. Cavalaria. História Militar.

Abstract: This article intends to analyze the military practices of the kingdoms of France and England during the initial phase of the Hundred Years' War, highlighting the performance of the Knighthood, an aristocratic force that came to be synonymous with the feudal order. To that end, the battles of Crécy (1346) and Poitiers (1356) were chosen as timeframe, as exceptional confrontations in which English armies of archers and warriors afootbeatthe French knights. There is a fundamental question guiding the paper: why the French Cavalry, even in the face of failure, did not seek to adapt to the realities of war, as the English did? The result is a study of the political and social elements of war in the Middle Ages, as well as a comparative exercise between the forms of military organization of these two kingdoms.

Keywords: Hundred Years' War. Knighthood.Military History.

${ }^{1}$ Mestrando do Programa de Pós-Graduação em História da Universidade Federal de Sergipe. Bolsista CAPES/DS. Integrante do Dominium: Estudos sobre Sociedades Senhoriais (CNPq-UFS). E-mail: ivesleocelso@gmail.com.

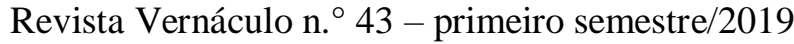

ISSN 2317-4021 
A Guerra dos Cem Anos (1337-1453) foi caracterizada por Hilário Franco Júnior ${ }^{2}$ como sendo ao mesmo tempo o grande conflito nacionalista e o grande conflito feudal da Idade Média. Duas das mais poderosas monarquias do período, França e Inglaterra, envolveram-se num longo e arrastado embate que teve inúmeras consequências políticas e sociais para ambos. Proeminente neste cenário, estava aquela que Jacques Le Goff considerou “[...] expressão mais característica do feudalismo" "3: a Cavalaria.

Por "cavalaria" compreendemos uma força de soldados montados, podendo existir em inúmeras formas e períodos (desde Kadesh até a Segunda Guerra Mundial, segundo Álvaro Bragança Júnior ${ }^{4}$ ). Distinguimos o termo "Cavalaria", contudo, para realçar os aspectos políticos, sociais, culturais e ideológicos de uma instituição própria do medievo.

A Cavalaria é uma confraria de guerreiros de elite, associados à nobreza, com a qual muitas vezes se confunde; possui uma ética própria, uma cultura de honra onde o comportamento cavaleiresco e a reputação são primordiais; e que é idealizada e alcança patamares míticos através da literatura e da poesia trovadoresca ${ }^{5}$. No século XIV é

${ }^{2}$ FRANCO JÚNIOR, Hiláro. A Idade Média: O Nascimento do Ocidente. 2 ed. rev. e ampl. São Paulo: Brasiliense, 2001.p. 86.

${ }^{3}$ LE GOFF, Jacques. Heróis e Maravilhas da Idade Média.2 ed. Petrópolis: Vozes, 2011. p. 93.

${ }^{4}$ BRAGANÇA JÚNIOR, Álvaro. A Cavalaria na Idade Média: Entre a Guerra e a Civilização. In: ZIERER, Adriana; Cavalaria e Nobreza: Entre a História e a Literatura. Maringá: Eduem, 2017. p. 25-45. p. 25.

${ }^{5}$ FLORI, Jean. A Cavalaria.São Paulo: Madras, 2005. passim.

Revista Vernáculo n. ${ }^{\circ} 43$ - primeiro semestre/2019

ISSN 2317-4021 
cada vez maior o número de soldados a cavalo que não possuem o título. Por outro lado, muitos cavaleiros passam a combater a pé, como será visto adiante.

Clifford J. Rogers, historiador norte-americano da Academia Militar de West Point especializado na guerra medieval,realiza uma comparação entre os exércitos medievais (metade do século XI a início do século XIV)e aqueles doprincípio da "Idade Moderna", que viriam a conquistar impérios globais para os príncipes europeus, estabelecendo os seguintes critérios: enquanto os primeiros eram formados por guerreiros aristocratas que lutavam como cavalaria pesada, usavam lança e espada, e combatiam mais para capturar e obter resgate que para matar; os segundos eram compostos por homens comuns do povo, que lutavam a pé, disparavam projéteis e lutavam para matar ${ }^{6}$.

A Guerra dos Cem Anos situa-se na transição entre ambos: apresenta a decadência militar da Cavalaria (e seu paradoxal fortalecimento ideológico) e o crescimento das forças de infantaria e, em sua fase final, da artilharia.

No período de 1346-1356, França e Inglaterra representam pólos opostos deste cenário. $\mathrm{O}$ exército inglês era formado por grande número de arqueiros recrutados por cavaleiros e senhores locais, que formam unidades regionais e lutam em conjunto com os homens-de-armas

${ }^{6}$ ROGERS, Clifford J. The Military Revolutions of the Hundred Years' War.The Journal of Military History, Lexington, v. 57, p. 1-33, 1993.Disponívelem: < http://deremilitari.org/2014/06/the-military-revolutions-of-the-hundred-years-war/>.p. 2.

Revista Vernáculo n. ${ }^{\circ} 43$ - primeiro semestre/2019

ISSN 2317-4021 
(denominação dos guerreiros montados, nobres ou não). O serviço era pago e as comitivas contratadas pelo rei e pagas pelo erário, que possuía uma burocracia bem desenvolvida. $O$ francês era, em essência, uma hoste de cavalaria aristocrática, reunida por meio de uma convocação geral, além de mercenários contratados, especialmente besteiros genoveses. Ainda que haja pagamento, espera-se que a convocação seja obedecida por lealdade e cumprimento do devervassálico ${ }^{7}$.

A nobreza de ambos os reinos abraçava os ideais da Cavalaria. Participavam dos mesmos torneios, enfrentavam-se nas mesmas justas e ouviam os mesmos poemas. Entretanto, diferenças cruciais seriam reveladas, especialmente a partir da Batalha de Crécy (1346), na forma de condução da guerra, com consequências desastrosas para a França.

\section{A Campanha de Crécy (1346)}

Após a morte de Filipe IV da França, três de seus filhos o sucederam sem deixar herdeiros masculinos. A aristocracia reunida decidiu, então, transmitir a coroa à Filipe, conde de Valois, seu sobrinho, que foi coroado Filipe VI em 1328. Entre os pretendentes rejeitados estava Eduardo III, o jovem rei da Inglaterra, neto de Filipe IV através de sua mãe. Complicando a questão, Eduardo era também duque de Aquitânia e, portanto, vassalo do rei francês.

${ }^{7}$ SUMPTION, Jonathan. The Hundred Years War v. I: Trial by Battle. Philadelphia: University of Pennsylvania Press, 1990. passim. Id. The Hundred Years War v. II: Trial by Fire. Philadelphia: University of Pennsylvania Press, 1999.passim.

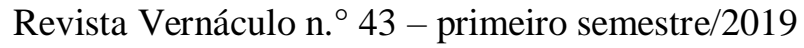

ISSN 2317-4021 
As tensões resultantes desta relação eram muitas e diversas vezes os monarcas franceses procuraram confiscar o ducado dos reis da Inglaterra, acusando-os de descumprir suas obrigações vassálicas. Quando Filipe tentou VI fazê-lo, em 1337, Eduardo, em uma manobra jurídica, recusou sua legitimidade para tal, afirmando ser o verdadeiro rei da França.Nigel Saul, historiador britânico da Universidade de Londresprominente no estudo da Cavalaria inglesa,ressalta o elemento cavaleiresco no desafio do rei inglês:

Para atrair atenção para seu novo título, ele dividiu seu escudo em quartos colocando a flor-de-lis do rei da França com os leões da Inglaterra. A Guerra dos Cem Anos foi, portanto, em um sentido técnico, uma disputa cavaleiresca, uma contenda entre dois cavaleiros pelo direito de portar um brasão em particular. ${ }^{89}$

De modo geral, a guerra medieval se caracterizava por evitar grandes batalhas, sendo as cavalgadas e os cercos suas características principais. Estes embates indiretos visavam espoliar a base econômica do inimigo, assolando seus homens e bens, assim como desmoralizá-lo e provocar seu enfraquecimento político ${ }^{10}$. Apesar disso, Philippe Contamine, medievalista francês pioneiro na pesquisa sobre a guerra no medievo naquele país, afirma que "[...] a batalha campal era concebida

${ }^{8}$ To draw attention to his new style, he quartered the fleur-de-lys of France on his shield with the lions of England. The Hundred Years War was therefore in a technical sense a chivalric dispute, a quarrel between two knights over the right to bear a particular coat of arms.

${ }_{9}^{9}$ SAUL, Nigel. Chivalry in Medieval England. Cambridge: Harvard University Press, 2011. p. 94-95.

${ }^{10}$ GARCÍA FITZ, Francisco. Ejércitos y Actividades Guerreras en la Edad Media Europea. Madri: Arco Libros, 1998.passim.

Revista Vernáculo n. ${ }^{\circ} 43$ - primeiro semestre/2019

ISSN 2317-4021 
como o ponto culminante de uma guerra, o grande evento que dava sentido a uma campanha, o episódio principal que, apesar de limitado em área e concentrado no tempo, era o objeto de todos os medos, expectativas e esperanças" $" 1112$.

A tática adotada por Eduardo III na França foi a chevauchée, grandes cavalgadas de propósito de pilhagem e destruição. Seus homens-de-armas e arqueiros montados espalhavam-se em vastas colunas atacando todas as fazendas, vilas e cidades que não oferecessem séria resistência. Durante a campanha de Crécy, o cronista Jean Froissart estabelece um cenário de saques abundantes, destacando a inatividade das forças francesas:

Eles faziam o que queriam, pois ninguém lhes resistia. Em tempo eles chegaram a uma grande e rica cidade e porto chamada Cherbourg. Eles a saquearam e queimaram parte dela, mas descobriram a cidade defendida demais para ser tomada, então seguiram adiante para Montbourg e Valogne. Esta última eles saquearam completamente e puseram-lhe fogo. Eles fizeram o mesmo a um número de outras cidades na região, levando tanto saque valioso que teria sido impossível contá-lo. ${ }^{1314}$

${ }^{11}[\ldots]$ the pitched battle was conceived as the culminating point of a war, the major event which made sense of a campaign, the chief episode which, although limited in area and concentrated in time, was the object of all fears, expectations and hopes.

12 CONTAMINE, Philippe. War in the Middle Ages. New York: Barnes \& Noble, 1998. p. 228-229.

${ }^{13}$ They did whatever they pleased, for no one resisted them. They came in time to a large wealthy town and port called Cherbourg. They sacked and burnt part of it, but found the citadel too strongly defended to be taken, so they went on towards Montbourg and Valogne. This last they sacked completely and then set fire to it. They did the same to a number of other towns in the region, taking so much valuable booty that it would have been an impossible task to count it.

Revista Vernáculo n. ${ }^{\circ} 43$ - primeiro semestre/2019

ISSN 2317-4021 
Eduardo, contudo, precisava atrair o monarca francês para a batalha, uma vez que suas campanhas de 1338 e 1340 haviam causado pesados gastos e obtido poucos resultados concretos. Uma vitória era necessária para manter viva sua reivindicação ao trono da França ${ }^{15}$.

Mas se a situação era politicamente delicada para o rei inglês, para Filipe VI era ainda pior. Após evitar batalha por duas vezes, a reputação do rei da França estava danificada. Andrew Ayton, historiador britânico da Universidade de Hull conhecido por seu trabalho sobre a Batalha de Crécy, afirma que um exército medieval é uma entidade política ${ }^{16}$ : nobres de todo o reino se reúnem; príncipes, duques e cavaleiros confraternizam, discutem e observam. O rei estava sob o escrutínio de seus senhores. De acordo com Jonatham Sumption, renomado pesquisador inglês da Guerra dos Cem Anos: "Em 1346 sua reputação não podia suportar um impasse mais do que uma derrota" ${ }^{1718}$.Uma batalha precisava ser travada.

Após uma perseguição pelas travessias do Sena, os exércitos finalmente se encontraram próximos à vila e à floresta de Crécy, no condado de Ponthieu. Os ingleses somavam cerca de 10.000 homens,

14 FROISSART, Jean. Chronicles.Trad. Geoffrey Brereton. Baltimore: Penguin Classics, 1968. p. 71.

${ }^{15}$ SAUL, Nigel. Chivalry in Medieval England. Cambridge: Harvard University Press, 2011.p. 95.

16 AYTON, Andrew. The Battle of Crécy: Context and Significance. In: ; PRESTON, Philip. The Battle of Crécy, 1346. Woodbridge: The Boydel Press, 2007. p. 21-22.

${ }^{17} \mathrm{By} 1346$ his reputation could not bear a stalemate any more than a defeat.

${ }^{18}$ SUMPTION, Jonathan. The Hundred Years War v. I: Trial by Battle. Philadelphia: University of Pennsylvania Press, 1990. p. 526.

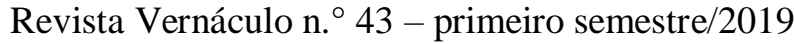

ISSN 2317-4021 
enquanto o número de franceses girava entre 20.000 e 25.000. As forças sob o comando de Eduardo III eram formadas por arqueiros (cerca de metade), cavaleiros desmontados e lanceiros galeses. Filipe VI tinha à sua disposição um contigente de cerca de 6.000 besteiros genoveses, 12.000 cavaleiros e alguns milhares de tropas de infantaria, provavelmente mal-treinada e mal-equipada $^{19}$. O que se seguiu foi um grande massacre.

O primeiro ataque foi realizado pelos besteiros genoveses. Suas armas de carregamento lento, contudo, não foram páreo para os disparos céleres dos arqueiros ingleses, que os dispersaram. Vendo sua fuga, o rei francês, furioso, ordenou o avanço de seus cavaleiros sobre eles, direto para os disparos dos arcos de guerra ${ }^{20}$.Segundo narra Froissart, "os ingleses continuaram a disparar na parte mais densa da multidão, sem desperdiçar nenhuma de suas flechas. Eles impalaram ou feriram cavalos e cavaleiros que caíam ao chão em grande desespero, incapazes de se levantar de novo sem a ajuda de vários homens" ${ }^{2122}$.

Dada a natureza da carga de cavalaria, uma massa sólida de homens e montarias, a chuva de flechas era letal, uma vez que os animais feridos rompiam a formação e causavam caos. Um ponto

${ }^{19}$ Ibid.

20 FROISSART, Jean. Chronicles.Trad. Geoffrey Brereton. Baltimore: Penguin Classics, 1968. p. 88-89.

${ }^{21}$ The English continued to shoot into the thickest part of the crowd, wasting none of their arrows. They impaled or wounded horsers and riders, who fell to the ground in great distress, unable do get up again without the help of several men.

22 FROISSART, Jean. Chronicles.Trad. Geoffrey Brereton. Baltimore: Penguin Classics, 1968. p. 89.

Revista Vernáculo n. ${ }^{\circ} 43$ - primeiro semestre/2019

ISSN 2317-4021 
relevante para a nossa análise, que será retomado adiante, é que, mesmo diante do fracasso, a honra cavaleiresca dos franceses os impelia a renovar os ataques, ocasionando baixas imensas. Guilherme Saccomori, em dissertação orientada pela professora Marcella Lopes Guimarães (UFPR), afirma que:

A honra de um cavaleiro seria oriunda de seus atos, principalmente em duelos e combates. A honra, seu orgulho como guerreiro, era o que guiava a identidade de um cavaleiro, the dava sentido. Engrandecê-la tornaria o cavaleiro alguém maior, famoso, e objeto de cantigas e poemas que seriam compostos a partir de seus feitos. Os combates justos o tornariam alguém superior quando confrontado em condições iguais. A honra estaria atrelada a um cavaleiro durante toda sua vida, e manchá-la poderia comprometer seu legado, inclusive seus filhos. ${ }^{23}$

Lutando por sua honra, um contingentefrancês conseguiu chegar até o Príncipe de Gales, Eduardo de Woodstock, que, aos 16 anos, estava em sua primeira batalha. Diante do ataque, o cavaleiro sir Thomas de Norwich foi enviado ao rei, que comandava a reserva, pedindo reforços, ao que Eduardo teria respondido:

- Está meu filho morto ou atordoado, ou tão seriamente ferido que não pode continuar lutando? - Não, graças a Deus - retrucou o cavaleiro - mas ele está sendo pressionado muito duramente e precisa muito de vossa ajuda. - Sir Thomas - respondeu o rei - volte para ele e para aqueles que o enviaram e diga-lhes para não me requisitarem hoje, enquanto meu filho estiver vivo. Dê-lhes

${ }^{23}$ SACCOMORI, Guilherme Floriani. Guerreiros e Batalhas na Mira de Jean Froissart (1337-1405): Cenário em Transformação. 2015. 121 f. Dissertação (Mestrado em História) - Departamento de História, Universidade Federal do Paraná, Curitiba, 2015. p. 67-68.

Revista Vernáculo n. ${ }^{\circ} 43$ - primeiro semestre/2019

ISSN 2317-4021 
meu comando para deixar o garoto ganhar suas esporas, pois se for a vontade de Deus, eu desejo que o dia seja dele e que a honra vá para ele e para aqueles em cuja custódia eu o deixei. ${ }^{2425}$

Esta cena, de forte teor simbólico, ressalta a proeza militar como valor aristocrático e a necessidade dos grandes senhores de se provarem em batalha. O Príncipe de Gales triunfou e com ele o exército inglês. As perdas francesas foram catastróficas, estimadas em milhares, mais lamentadas ainda pelo grande número de aristocratas entre eles. Segundo Jean le Bel: "Foi dito por muito tempoque ninguém havia ouvido falar de tantos príncipes mortos em um único dia, nem em Courtrai, nem em Benevento, nem em nenhum outro lugar"2627.

A vitória em Crécy permitiu aos ingleses a tomada de Calais, grande cidade do norte da França que viria a permanecer em suas mãos até a metade do século XVI, muito após o término da Guerra dos Cem Anos. Enquanto a elite da Cavalaria francesa jazia no campo de batalha,

24 'Is my son dead or stunned, or so seriously wounded that he cannot go on fighting?' 'No, thank God,' replied the knight, 'but he is very hard pressed and needs your help badly.' ' Sir Thomas,' the King answered, 'go back to him and to those who have sent you and tell them not to send for me again today, as long as my son is alive. Give them my command to let the boy win his spurs, for if God has so ordained it, I wish the day to be his and the honour to go to him and to those in whose charge I have placed him.'

${ }^{25}$ FROISSART, Jean. Chronicles.Trad. Geoffrey Brereton. Baltimore: Penguin Classics, 1968. p. 92.

${ }^{26}$ It was said for a long time that no one had heard of so many princes killed on a single day, not at Courtrai, nor at Benevento, nor anywhere else.

${ }^{27}$ apud AYTON, Andrew. The Battle of Crécy: Context and Significance. In: ; PRESTON, Philip. The Battle of Crécy, 1346. Woodbridge: The Boydel Press, 2007.p. 20.

Revista Vernáculo n. ${ }^{\circ} 43$ - primeiro semestre/2019

ISSN 2317-4021 
Filipe VI escapava. A perda de reputação causada pela fuga do rei se tornaria uma marca sobre os Valois e seria um fator importante na política militar adotada pela realeza na década seguinte.

\section{A Ordem da Estrela e a Reforma Cavaleiresca de João II}

Segundo a medievalista francesa Françoise Autrand:

O desastroso efeito psicológico produzido pela fuga do rei não foi esquecido durante os anos após Crécy; de fato, não é impossível que tenha tido alguma influência sobre a fundação da 'Ordem da Estrela'. Em 1351, o rei João tinha acabado suceder ao trono e querendo trazer as fileiras da comunidade cavaleiresca francesa, instiuiu a Ordem dos 'chevaliers de Notre-Dame de la Noble Maison' [...]. ${ }^{2829}$

A Ordem da Estrela, pretendia rivalizar a Ordem da Jarreteira, de Eduardo da Inglaterra, que reunia em suas fileiras veteranos da Campanha de Crécy e viria a se tornar a mais prestigiosa ordem cavaleiresca do período. Sobre a Ordem da Jarreteira, Saul afirma que:

De modo geral, o ethos da companhia era fortemente militar. Grande ênfase era colocada nos estatutos no esforço cavaleiresco e na lealdade ao rei como superior da ordem. Os cavaleiros eram escolhidos por eleição baseada em seu

${ }^{28}$ The disastrous psychological effect produced by the flight of the king was not forgotten during the years that followed Crécy; indeed, it is not impossible that it had some influence on the foundation of the 'Order of the Star'. In 1351, King John who had just succeeded to the throne, and wanting to draw the ranks of the French chivalric community more closely around the crown, instituted the Order of the 'chevaliers de Notre-Dame de la Noble Maison' [...].

${ }^{29}$ AUTRAND, Françoise. The Battle of Crécy: A Hard Blow for the Monarchy of France. In: AYTON, Andrew; PRESTON, Philip. The Battle of Crécy, 1346. Woodbridge: The Boydel Press, 2007. p. 276-277.

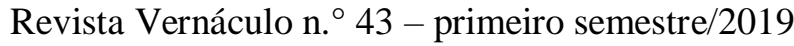

ISSN 2317-4021 
valor pessoal, seu renome marcial e a natureza imaculada de suas reputações. ${ }^{3031}$

As ordens reais de Cavalaria foram um fenômeno característico dos séculos XIV e XV. A seu respeito, Jean Flori, conhecido especialista francês em Cavalaria,observa:

Protegidas por reis ou grandes príncipes rivais ou inimigos, elas elaboram estatutos que, sob a aparência de glorificar e "restaurar" a cavalaria, constituem ligas honoríficas destinadas a reforçar o prestígio de seu fundador, a forjar redes de alianças políticas e diplomáticas. A ideologia cortês e cavalheiresca se vê assim confiscada, desviada em proveito da ideologia real. ${ }^{32}$

O que diferencia a Ordem da Estrela das demais ordens monárquico-cavaleirescas do século XIV é um de seus estatutos que determina que aquele que fugir do campo de batalha seria suspenso, no qual é notável o peso que a fuga de Filipe VI exercia sobre a Cavalaria francesa ${ }^{33}$.Em uma carta de autoria de João II, datada de 1352 e transcrita pelo especialista em heráldicaD'Arcy Boulton, percebe-se a forma como a Cavalaria era percebida no período pós-Crécy e a motivação que levou à fundação da referida companhia:

${ }^{30}$ Overall, the ethos of the company was strongly military. Great emphasis was placed in the statutes on knightly endeavor and loyalty to the king as superior of the order. Knights were to be chosen for election on the basis of their personal worthiness, their martial renown and the unblemished nature of their reputations.

${ }^{31}$ SAUL, Nigel. Chivalry in Medieval England. Cambridge: Harvard University Press, 2011. p. 103.

${ }^{32}$ FLORI, Jean. A Cavalaria.São Paulo: Madras, 2005. p. 185.

${ }^{33}$ AUTRAND, op. cit. p. 277.

Revista Vernáculo n. ${ }^{\circ} 43$ - primeiro semestre/2019

ISSN 2317-4021 
João pela Graça de Deus Rei da França... Entre outras preocupações de nossa mente, nós temos muitas vezes nos perguntado com toda a energia da reflexão por quais meios a cavalaria de nosso reino tem, desde tempos antigos, enviado para todo o mundo tamanha irrupção de probidade e tem sido coroada com uma auréola tão vívida de valentia e honra; de tal modo que nossos ancestrais, os Reis da França, graças a intervenção poderosa do céu e à fiel devoção desta cavalaria, que lhes concedeu o sincero e unânime suporte de suas armas, tem sempre triunfado sobre sobre todos os rebeldes a quem desejaram reduzir [...]; e finalmente que eles tenham estabelecido no reino uma paz e segurança tão profundos que, após muitos longos séculos, alguns dos membros desta ordem, desacostumados às armas e privados de exercícios, ou por outra causa por nós desconhecida, tem se atirado imoderadamente na ociosidade e na vaidade da época, ao desprezo da honra e, lamentavelmente, de seu próprio bom renome, para diminuir sua alegria de coração em troca do conforto de suas pessoas. Por esta razão, nós, conscientes de tempos passados, da honrada e constante proeza dos vassalos mencionados, que trouxeram tantos trabalhos vitoriosos, virtuosos e afortunados, resolvemos com sinceridade convocar estes mesmos vassalos, presentes e futuros, para uma união perfeita, com a finalidade de que nesta união íntima eles irão respirar nada além de honra e glória, reunciando às frivolidades da inação, e irão, através do respeito pelo prestígio da nobreza e da cavalaria, restorar à nossa época o brilho de seu renome antigo e de sua companhia ilustre, e que depois que eles tiverem trazido o reflorescimento da honra da cavalaria através da proteção do bem divino, uma paz tranquila renascerá para o nosso reino e os nossos súditos, e os louvores a sua virtude serão publicados em toda a parte. Desta forma, na expectativa destes benefícios e de muitos outros, nós... fundamos [a Companhia da Estrela e seu colégio de clérigos]. E nós temos firme confiança de que com a intercessão da dita mais gloriosa Virgem Maria por nós e por nossos fiéis súditos, o Senhor Jesus Cristo irá misericordiosamente derramar sua graça sobre os cavaleiros da mencionada companhia ou associação, com o resultado de que estes mesmos cavaleiros, ansiosos por honra e glória no exercício das armas, se portarão com tal harmonia e valentia, que a 
flor da fidalguia, que por um tempo e pelas razões mencionadas tinha murchado nas sombras, irá desabrochar em nosso reino, e brilhar resplandecente em uma perfeita harmonia para a honra e glória do reino e de nossos súditos fiéis. ${ }^{3435}$

${ }^{34}$ Jean by the Grace of God King of France... Among the other preoccupations of our mind, we have many times asked ourself with all the energy of reflection, by what means the knighthood of our realm has, from ancient times, sent forth into the whole world such a burst of probity, and has been crowned with so lively an aureole of valiance and honour; so well that our ancestors the Kings of France, thanks to the powerful intervention of heaven and to the faithful devotion of this knighthood, which has bestowed upon them the sincere and unanimous concourse of its arms, have always triumphed over all the rebels whom they have wished to reduce [...]; and finally that they had established in the realm a peace and security so profound that, after many long centuries, some of the members of this order, unaccustomed to arms and deprived of exercises, or for some other cause unknown to us, have immoderately plunged themselves into the idleness and vanity of the age, to the contempt of honour, alas, and of their good renown, to diminish their gaiety of heart in exchange for the comfort of their persons. For this reason we, mindful of former times, of the honourable and constant prowess of the aforesaid liegemen, who brought forth so many victorious, virtuous, and fortunate works, have taken it to heart to recall these same liegemen, present and future, to a perfect union, to the end that in this intimate unity they will breathe nothing but honour and glory, renouncing the frivolities of inaction, and will, through respect for the prestige of the nobility and knighthood, restore to our epoch the lustre of their ancient renown and of their illustrious company, and that after they have brought about the reflowering of the honour of knighthood through the protection of divine goodness, a tranquil peace will be reborn for our reign and our subjects, and the praises of their virtue will be published everywhere. Therefore, in expectation of these benefits and of many others, we ... have founded [the Company of the Star and its college of clerics]. And we have firm confidence that with the intercession of the said most glorious Virgin Mary for us and our faithful subjects, the Lord Jesus Christ will mercifully pour out his grace upon the knights of the aforesaid company or association, with the result that the same knights, eager for honour and glory in the exercise of arms, shall bear themselves with such concord and valiance, that the flower of chivalry, which for a time and for the reasons mentioned had faded into the shadows, shall blossom in our realm, and shine resplendent in a perfect harmony to the honour and glory of the kingdom and of our faithful subjects.

${ }^{35}$ BOULTON, D'Arcy J. D. Knights of the Crown: The Monarchical Orders of Knighthood in Later Medieval Europe, 1325-1520.Woodbrige, TheBoydel Press, 1987.p. 196.

Revista Vernáculo n. ${ }^{\circ} 43$ - primeiro semestre/2019

ISSN 2317-4021 
O retorno à era de ouro da Cavalaria é um tema recorrente entre seus comentadores na Baixa Idade Média, com alusões frequentes aos Cavaleiros da Távola Redonda e aos guerreiros de Carlos Magno. Esta retórica de apelo a um passado mitificado era tão forte na França que os mesmos argumentos se repetem após a derrota em Agincourt (1415) duas gerações após os eventos aqui expostos ${ }^{36}$.

A fala de João II deixa claro que as agruras sofridas pelo reino eram causadas pela perda do valor de seus cavaleiros. Os termos honra e glória são continuamente repetidos como valores a serem buscados acima de considerações superficiais com conforto e segurança pessoal. Sob este ângulo, a derrota em Crécy e a perda de Calais não foram causadas por questões táticas ou puramente militares, mas por falta de coragem e resolução. Isto não deixa de ser irônico, visto que a grande perda de vidas ocorrida na batalha de 1346 foi causada em grande parte pela bravura teimosa dos homens-de-armas franceses que continuaram avançando diante da morte.

Não se deve compreender, contudo, o projeto reformador de João II e sua Ordem da Estrela como uma tentativa desinteressada de reacender a glória militar da nobreza da França. O rei pretendia ligar os cavaleiros a ele por vínculos de lealdade e fidelidade, fortalecendo assim sua posição num momento em que a jovem dinastia Valois era

${ }^{36}$ BARKER, Juliet. Agincourt. Rio de Janeiro: Record, 2009. passim.

Revista Vernáculo n. ${ }^{\circ} 43$ - primeiro semestre/2019

ISSN 2317-4021 
ameaçada externa e internamente. Dissensão e faccionalismo predominaram na política francesa na Guerra dos Cem Anos ${ }^{37}$.

O braço direito de João II na sua tentativa de "revitalização" da Cavalaria foi Geoffroi de Charny, autor do Livro da Cavalaria, escrito provavelmente entre 1350 e 1351. Nascido em uma família dos baixos escalões da aristocracia, Charny era um cavaleiro de grande reputação, considerado por Froissart o mais sábio e corajoso entre os franceses ${ }^{38}$. Não tendo estado em Crécy, não foi associado à sua infâmia e por sua habilidade militar, foi nomeado Capitão das Guerras da Picardia e das Fronteiras da Normandia e ingressou no Conselho Real ${ }^{39}$.

Charny compartilhava da visão de seu rei e parecia chocado por aqueles que“[...] aparentavam preferir a vida suave e a vida fácil, cegos para a grandiosa visão de uma existência investida em feitos vigorosos, [...] uma vida de honra abençoada pelo favor divino" ${ }^{4041}$.Sem dúvida com a aprovação de João II, Charnyjustifica as razões para se servir a um grande senhor:

${ }^{37}$ SUMPTION, Jonathan. The Hundred Years War v. II: Trial by Fire. Philadelphia: University of Pennsylvania Press, 1999.passim.

38 FROISSART, Jean. Chronicles.Trad. Geoffrey Brereton. Baltimore: Penguin Classics, 1968. p. 129.

${ }^{39}$ KAEUPER, Richard. Historical Introduction to the Text. In: CHARNY, Geoffroi de. A Knight's Own Book of Chivalry. Trad. Elspeth Kennedy. Philadelphia: University of Pennsylvania Press, 2005.passim.

${ }^{40}[\ldots]$ appeared to prefer the soft life and the safe life, blind to the grand vision of an existence vested in vigorous deeds, [...], a life of honour blessed by divine favour.

${ }^{41}$ KAEUPER, Richard W. Chivalry and Violence in Medieval Europe. Oxford: Oxford University Press, 1999. p. 285.

Revista Vernáculo n. ${ }^{\circ} 43$ - primeiro semestre/2019

ISSN 2317-4021 
[...] cem homens habilidosos em feitos de armas fazem um nome pra si mesmos muito mais rápido através de um grande e valoroso senhor do que fariam dez servindo a dois homens pobres de grande valor, pois o grande senhor os tem em sua companhia e os ama, honra, valoriza e recompensa, e eles o respeitam, amam, honram e estimam pelo grande valor que vêem nele [...]. Nem são os homens pobres e valentes tão respeitados e obedecidos no momentos da ação quanto os grandes senhores [...]. ${ }^{4243}$

Que melhor maneira de conquistar fama e fortuna, desta forma, do que servindo ao rei em sua na Ordem da Estrela?Ao contrário de sua contraparte inglesa, de número estritamente limitado, a Ordem da Estrela pretendia alcançar quinhentos adeptos ${ }^{44}$.

Contudo, por mais que se falasse em recuperar o espírito perdido da verdadeira Cavalaria e por mais que Charny ${ }^{45}$ discorra sobre o comportamento apropriado para um cavaleiro, pouco foi feito para lidar com os problemasconcretos que assolavam as forças francesas e que seriam expostas mais uma vez na Batalha de Poitiers, em 1356. As razões para tanto serão examinadas a seguir.

\footnotetext{
${ }^{42}[\ldots]$ one hundred men skilled in deeds of arms make themselves a name all the sooner through one great and worthy lord than would ten by two poor men of great worth, for the great lord has them in his company and loves, honors, and values them and rewards them, and they respect him, love, honor, and esteem him for the great valor they see in him [...]. Nor are the valiant poor men as much respected and obeyed in time of action as are the great lords $[\ldots]$.

${ }^{43}$ CHARNY, Geoffroi de.A Knight's Own Book of Chivalry. Trad. Elspeth Kennedy. Philadelphia: University of Pennsylvania Press, 2005. p. 59.

${ }^{44}$ WAGNER, John A. Encyclopedia of the Hundred Yeas War. Westport: Greenwood Press, 2006.p. 289.

${ }^{45}$ CHARNY, op. cit. passim.
}

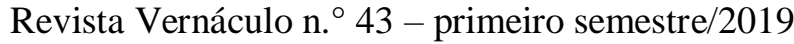

ISSN $2317-4021$ 


\section{Considerações políticas e militares sobre a prática da guerra na}

\section{França e na Inglaterra no século XIV}

O papel proeminente da Cavalaria, muito antes de sua consagração no imaginário medieval, tem uma origem militar:

O cavaleiro medieval, sustentado como era pelo trabalho de outrem, possuía bastante tempo para treinar para o combate. Sua dieta melhor o tornava maior e mais forte que a maioria dos plebeus que formavam a infantaria. [...] A cota de malha, reforçada por uma couraça de couro ou um gambeson acolchoado, o tornava quase invulnerável no campo de batalha. A mobilidade permitida por seus cavalos, em adição a seu óbvio valor estratégico, o tornava capaz de perseguir um inimigo derrotado com eficiência, de fugir rapidamente em caso de derrota própria e de evitar batalhas indesejadas com forças lentas de infantaria. ${ }^{4647}$

A França era tão populosa e possuía uma riqueza agrícola tão vasta, que conseguia reunir com frequência verdadeiras hostes de guerreiros montados. Outros reinos e regiões periféricos, tais como a Escócia, Flandres e a própria Inglaterra, tinham dificuldades em recrutar

${ }^{46}$ The medieval knight, supported as he was by the labor of others, had plenty of time to train for combat. His better diet made him larger and stronger than most of the commoners who formed de infantry. Most importantly, the capital he had invested in horses, arms, and armor magnified his capabilities. Mail armor, reinforced by a leather cuirass or a padded gambeson, made him nearly invulnerable on the battlefield. The mobility afforded by his horses, in addition to its obvious strategic value, enabled him to pursue a defeated enemy effectively, to flee rapidly if himself defeated, and to avoid unwanted battles with slow-moving infantry forces.

47 ROGERS, Clifford J. The Military Revolutions of the Hundred Years' War.The Journal of Military History, Lexington, v. 57, p. 1-33, 1993.Disponívelem: < http://deremilitari.org/2014/06/the-military-revolutions-of-the-hundred-years-war/> . p. 3.

Revista Vernáculo n. ${ }^{\circ} 43$ - primeiro semestre/2019

ISSN 2317-4021 
cavaleiros, razão pela qual passaram a utilizar cada vez mais soldados de infantaria, muito mais baratos de equipar e manter ${ }^{48}$.

Há que se destacar, porém, a transformação pela qual a Inglaterra passou no início do século XIV. Assim como os franceses, os ingleses contavam com a cavalaria pesada para garantir a vitória. Isto mudou após Batalha de Banockburn, em 1314, na qual guerreiros escoceses a pé, lutando em em schiltrons - formações circulares armadas com piques - venceram os cavaleiros ingleses. Além de usarem armas longas, os escoceses prepararam o terreno, cavando buracos e fincando estacas para desequilibrar os cavalos. Os ingleses aprenderam a lição e, além de adotarem diversas táticas dos escoceses, acrescentaram um elemento próprio: os arqueiros.

$\mathrm{O}$ arco longo ou arco de guerra era praticado em diversas regiões da Inglaterra e do País de Gales por aldeãos e agricultores. Para utilizá-lo eram necessários anos de prática e força física prodigiosa, mas seu poder de penetração era incrível, além de possuir um ritmo de disparo incomparavelmente superior ao das bestas ${ }^{49}$. Uma salva contínua de flechas podia ferir, atordoar e incapacitar homens e cavalos. A utilização dos arqueiros permitiu que os ingleses obtivessem a revanche sobre os escoceses em Duplin Moor (1332) e Halidon Hill

${ }^{48}$ ROGERS, Clifford J. The Age of The Hundred Years War. In: KEEN, Maurice (ed.). Medieval Warfare: A History. Oxford: Oxford University Press, 1999. p. 136160.p. 144.

${ }^{49}$ Id. The Military Revolutions of the Hundred Years' War.The Journal of Military History, Lexington, v. 57, p. 1-33, 1993.Disponível em: < http://deremilitari.org/2014/06/the-military-revolutions-of-the-hundred-years-war/>. p. 5 .

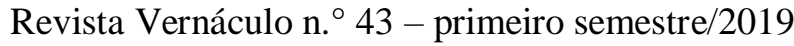

ISSN $2317-4021$ 
(1333). Por outro lado, as forças que invadiram a França utilizaram arqueiros montados, uma inovação para a época, o que facilitava seu deslocamento e sua participação no saque das vilas e campos. Seus cavalos, que não eram utilizados em batalha, eram muito mais baratos que os corcéis de guerra dos cavaleiros, e mais fáceis de obter ${ }^{50}$.

A França, por sua vez, também teve sua forma tradicional de combate soprebujada em certas ocasiões, como na Batalha de Courtrai (1302), onde milicianos flamengos utilizaram armas de haste e um terreno favorável para vencer sua Cavalaria. Isto não levou, contudo, a uma perceptível adaptação, ou mudança de táticas. As razões para tal não podem ser exauridas dentro dos limites deste trabalho, mas algumas reflexões podem ser iniciadas.

A França do século XIV era considerada o maior poderio militar da Cristandade. A história da Cavalaria perpassa a sua própria e os nobres franceses percebiam-secomo herdeiros de uma longa tradição que remontava ao Império Carolíngio, o que pode ajudar a explicar o seu conservadorismo. Na Inglaterra, por outro lado, por muitos séculos prevaleceu o combate de infantaria. Tanto anglo-saxões, quanto dinamarqueses, galeses e escoceses lutavam a pé, geralmente em uma parede de escudos. Somente com a conquista normanda é que lutar a cavalo tornou-se comum.

${ }^{50}$ SUMPTION, Jonathan. The Hundred Years War v. II: Trial by Fire. Philadelphia: University of Pennsylvania Press, 1999.passim.

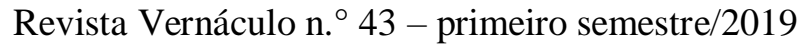

ISSN 2317-4021 
Entretanto, a cultura cavaleiresca floresceu na Inglaterra. Um dos maiores heróis da Cristandade, Ricardo Coração-de-Leão, havia sido seu rei e Eduardo IIItera um entusiasta dos torneios e dos romances arturianos, chegando a competir nas justas disfarçado como um dos Cavaleiros da Távola Redonda ${ }^{51}$.Porém, no século XIV, parecia haver uma limite estabelecido entre o lúdico e o real. Na prática da guerra, a aristocracia inglesa não hesitava em tirar proveito de todas as vantagens possíveis, fosse combatendo a pé, fosse mantendo sua posição enquanto os arqueiros atacavam.

A elite francesa, por outro lado, parecia incorporarde forma muito mais literal o exercício da Cavalaria. Preferiam lutar sobre os cavalos e demonstravam desprezo pelos soldados a pé, conforme demonstrado pelo investida contra seus aliados genoveses em Crécy. O desejo por honra e glória fizeram com que diversas vezes os cavaleiros franceses atacassem impetuosamente ou abandonassem a liderança das tropas em busca de uma posição mais privilegiada no campo ${ }^{52}$. Ao contrário do que seus críticos afirmavam, a bravura e o espírito cavaleiresco não parecem ter sido o que lhes faltava, sendo na verdade um fator em sua ruína.

${ }^{51}$ SAUL, Nigel. Chivalry in Medieval England. Cambridge: Harvard University Press, 2011.p. 105.

${ }^{52}$ SUMPTION, Jonathan. The Hundred Years War v. I: Trial by Battle. Philadelphia: University of Pennsylvania Press, 1990. passim. Id. The Hundred Years War v. II: Trial by Fire. Philadelphia: University of Pennsylvania Press, 1999.passim. BARKER, Juliet. Agincourt. Rio de Janeiro: Record, 2009.passim.

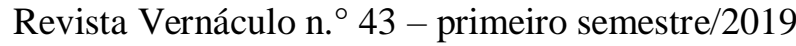

ISSN 2317-4021 
Por outro lado, há que se considerar o elemento político. Adinastia dos Plantagenetas estava solidamente estabelecida no poder, enquanto os Valois eram recém-chegados ao trono, mais vulneráveis a contestações. Abraçar o discurso cavaleiresco era uma forma da realeza buscar legitimidade, uma vez que, segundo Geoffroi de Charny, "estes personagens e estes senhores não foram elevados para terem grandes períodos de descanso, nem grandes prazeres ou grandes deleites, mas para suportar mais e esforçar-se com mais empenho do que quaisquer outros. $^{5354}$

Caberia, portanto, aos monarcas franceses realizar feitos de proeza e alcançar a vitória, obtendo assim honra e reputação, demonstrando o favor divino à sua causa e legitimando sua posição. Além disso, havia a presença de poderosos príncipes territoriais dentro de seu próprio reino, o que exigia dos reis da França um grau maior de negociação para o exercício de seu poder. Para conquistar o apoio da aristocracia, representar o papel tradicional de cavaleiro era uma necessidade.

Há também um elemento social na relutância francesa em se adaptar às novas táticas uma vez que há, no caso inglês, uma correlação entre a utilização cada vez maior de camponeses e citadinos no exército e o crescimento do poder da Câmara dos Comuns no Parlamento. A

${ }^{53}$ These personages and these lords were not raised up to have great periods of rest nor great pleasures nor great delights, but to endure more and to strive harder than any of the others.

${ }^{54}$ CHARNY, Geoffroi de.A Knight's Own Book of Chivalry. Trad. Elspeth Kennedy. Philadelphia: University of Pennsylvania Press, 2005. p. 76.

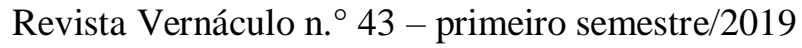

ISSN 2317-4021 
participação dos homens comuns na guera se convertia num aumento de suas demandas, bem como numa regulamentação cada vez mais incisiva sobre os impostos e taxações. Por outro lado, os arqueiros tiveram uma grande participação na Revolta Camponesa de 1381 e Froissart afirma que seu principal líder, Wat Tyler, havia servido nas guerras na França $^{55}$. Talvez para evitar um possível fortalecimento das classes inferiores, a nobreza francesa tenha desistido de tentar recrutar arqueiros em suas terras - Carlos VI teria afirmado que "se eles tivessem sido reunidos, teriam sido mais poderosos do que príncipes e nobres" $" 5657$.

As razões para a divergência na forma de realizar a guerra entre os reinos da França e da Inglaterra na metade do século XIV são complexas e merecem estudo aprofundado. O que se observa é que no início da década de 1350 acreditava-se que se os cavaleiros franceses redobrassem seus esforços e se inspirassem na tradição cavaleiresca de seus antepassados, a vitória seria alcançada. Em pouco tempo esta teoria seria testada, com resultados desastrosos.

55 FROISSART, Jean. Chronicles.Trad. Geoffrey Brereton. Baltimore: Penguin Classics, 1968. p. 218.

${ }^{56}$ If they had been gathered together, would have been more powerful than princes and nobles.

${ }^{57}$ apud ROGERS, Clifford J. The Military Revolutions of the Hundred Years' War.The Journal of Military History, Lexington, v. 57, p. 1-33, 1993.Disponívelem: < http://deremilitari.org/2014/06/the-military-revolutions-of-the-hundred-years-war/>. p. 6.

Revista Vernáculo n. ${ }^{\circ} 43$ - primeiro semestre/2019

ISSN 2317-4021 


\section{O fim da Ordem da Estrela e a Batalha de Poitiers (1356)}

Em 1352, após um enfrentamento próximo à cidade de Mauron, na Bretanha, "os cadáveres de oitenta e nove cavaleiros da Ordem da Estrela de João II foram encontrados entre os mortos, cercados pelos de seus escudeiros e seguidores" ${ }^{\$ 5859}$. Seguindo os preceitos da ordem, eles não haviam se retirado do campo de batalha, mesmo enquanto outras divisões francesas o faziam.

Este evento, que poderia ser relegado a uma pequena escaramuça não fosse o número de mortos envolvidos, pairava como um agouro sobre a reforma cavaleiresca do rei da França. Segundo John Wagner: "Em outubro de 1352 o rei reconheceu esta falha emitindo um decreto que transformava a ordem de uma instiuição políticocavaleiresca em uma confraternidade para culto comum" ${ }^{\text {,6061 }}$.

Em 1355, o agora veterano Príncipe de Gales conduziu uma grande chevauchée de Bordeaux ao Mediterrâneo e de volta, capturando diversas cidades e castelos e arrasando a economia do sul da França. Para complicar a situação, o reino estava à beira da guerra civil, com

${ }^{58}$ The corpses of eighty-nine knights of John II's Order of the Star were found among the dead, surrounded by those of their squires and retainers.

${ }^{59}$ SUMPTION, Jonathan. The Hundred Years War v. II: Trial by Fire. Philadelphia: University of Pennsylvania Press, 1999. p. 95.

${ }^{60}$ In October 1352, the king acknowledged this failure by issuing an ordinance that transformed the order from a political chivalric institution to a confraternity for common worship.

${ }^{61}$ WAGNER, John A. Encyclopedia of the Hundred Yeas War. Westport: Greenwood Press, 2006. p. 289.

Revista Vernáculo n. ${ }^{\circ} 43$ - primeiro semestre/2019

ISSN 2317-4021 
uma escalada de conflitos entre os Valois e os partidários de Carlos de Navarra, cunhado de João II e pretendente à coroa ${ }^{62}$.

João II não podia ignorar o exército inglês, assim como seu pai não pôde fazê-lo dez anos antes. Em 1356, conduziu uma força de cerca de 8.000 homens-de-armas e 3.000 tropas de infantaria para as proximidades de Poitiers, onde Eduardo de Woodstock o esperava com cerca de 6.000 homens, sendo 2.000 arqueiros, 1.000 infantes gascões e 3.000 homens-de armas. Mais uma vez a quantidade de combatentes montados franceses era superior ao todo do contingente inglês, desta vez, entretanto, decidiram que a maioria deles lutaria a pé - algo que não estavam acostumados a fazer -

pois os ingleses estavam no topo de uma colina protegidos por uma cerca-viva, o que impediria uma carga de cavalaria ${ }^{63}$.

Ainda assim, uma força de elite de 500 guerreiros a cavalo sob o comando dos marechais Audrehem e Clermont foi designada para atacar os arqueiros nas alas do exército inglês. Entretanto, de acordo com Froissart:

Mal haviam entrado em ação quando os arqueiros começaram a disparar sanguinariamente de ambos os flancos, derrubando cavalos e e perfurando tudo diante deles com suas longas flechas farpadas. Os cavalos feridos e aterrorizados se recusaram a ir em frente. Eles desviaram ou voltaram, ou então caíram sob seus cavaleiros, que não

${ }^{62}$ FROISSART, Jean. Chronicles.Trad. Geoffrey Brereton. Baltimore: Penguin Classics, 1968.p. 120.

${ }^{63}$ SUMPTION, Jonathan. The Hundred Years War v. II: Trial by Fire. Philadelphia: University of Pennsylvania Press, 1999. p. 235-236.

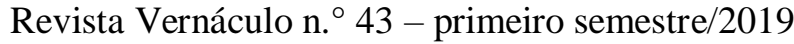

ISSN 2317-4021 
podia nem usar suas armas nem levantar novamente, de forma que o batalhão dos Marechais jamais chegou perto da divisão do príncipe. ${ }^{6465}$

O contingente desmontado francês estava ordenado em três divisões, liderados respectivamente pelo Delfim, o príncipe herdeiro da França, o duque de Orléans e o próprio rei. Após o ataque da cavalaria, as forças do Delfim se engajaram no combate, mas não conseguiram romper a linha inglesa e recuaram. Possivelmente por ordem do rei, o Delfim foi removido da batalha por seus companheiros. Contudo, "o duque de Orléans, vendo o Delfim se retirando, o seguiu para fora do campo, levando com ele os jovens condes de Anjou e Poitiers e toda a segunda linha",6667.

Esta decisão inexplicável realça os problemas de comando do exército francês. Não se sabe se o duque achou que uma retirada geral estava sendo feita ou se abandonou o campo por outra razão, mas o fato é que a divisão do rei ficou sozinha. João II, determinado a não cair em desgraça como seu pai havia feito, e seguindo os preceitos que impusera à Ordem da Estrela, liderou sua divisão para o combate:

${ }^{64}$ No sooner were they engaged in it than the archers began to shoot murderously from both flanks, knocking down horses and piercing everything before them with their long barbed arrows. The injured and terrified horses refused to go on. They swerved or turned back, or else fell beneath their riders, who could neither use their weapons nor get up again, so that the battaUon of the Marshals never got near the Prince's division.

${ }^{65}$ FROISSART, op. cit., p. 134-135.

${ }^{66}$ The Duke of Orléans, seeing the Dauphin leaving, followed him from the field taking with him the young Counts of Anjou and Poitiers and the whole of the second line.

${ }^{67}$ SUMPTION, Jonathan. The Hundred Years War v. II: Trial by Fire. Philadelphia: University of Pennsylvania Press, 1999. p. 241-242.

Revista Vernáculo n. ${ }^{\circ} 43$ - primeiro semestre/2019

ISSN 2317-4021 
Nem deveria ser dito que o Rei da França alguma vez mostrou desalento diante de qualquer coisa que viu ou ouviu reportarem. Ele permaneceu no campo do começo ao fim, como o cavaleiro corajoso e lutador resoluto que era. Ele havia demonstrado sua determinação de nunca bater em retirada quando comendou seus homens a lutarem a pé e, tendo-os feito desmontar, fez o mesmo e se posicionou na frente deles com um machado de batalha em suas mãos, ordenando seus estardantes avante em nome de Deus e Saint-Denis, com sir Geoffroi de Charny carregando o principal $^{68}$. ${ }^{670}$

Enquanto a linha de frente de ambos os exércitos estava engajada num intenso corpo-a-corpo, destacamentos montados de gascões e ingleses deram a volta pela retaguarda e atacaram os franceses por trás. Ironicamente esta foi, segundo Jonathan Sumption, “[...] uma das raras ocasiões em que a cavalaria decidiu uma grande batalha"7172 . Cercados, os franceses tiveram de escolher entre render-se ou lutar até o fim:

Os ingleses e gascões vieram em tais números por todos os lados que estraçalharam a divisão do rei. Os franceses foram tão sobrecarregados por seus inimigos que em alguns lugares haviam cinco homens-de-armas atacando um único

${ }^{68}$ A Oriflamme, o estandarte sagrado dos reis da França.

${ }^{69}$ Nor should it be said that the King of France ever showed dismay at anything he saw or heard reported. He remained on the field from beginning to end, like the brave knight and stout fighter he was. He had shown his determination never to retreat when he commanded his men to fight on foot and, having made them dismount, he did the same and stood in the forefront of them with a battle-axe in his hands, ordering forward his banners in the name of God and St Denis, with Sir Geoffroy de Charny bearing the principal one.

70 FROISSART, Jean. Chronicles.Trad. Geoffrey Brereton. Baltimore: Penguin Classics, 1968. p. 138.

${ }^{71}$ It was one of the rare occasions on which cavalry decided a great battle.

${ }^{72}$ SUMPTION, op. cit., p. 242. 
cavaleiro. Sir Geoffroi de Charny foi morto, o estandarte da França em suas mãos. ${ }^{7374}$

Em sua tese de doutorado, Carmem Druciak, também orientada pela professora Marcella Lopes Guimarães (que aos poucos está fazendo escola na Universidade Federal no Paraná na pesquisa sobre Guerra dos Cem Anos no Brasil), afirma que "odesastre na batalha de Poitiers em 1356 ficou registrado nas crônicas e nos tratados religiosos como uma falha da nobreza que compunha as linhas das hostes de Jean II, Le Bon"75.Abandonado pelo duque de Orléans, o rei da França, juntamente com seu filho mais novo, Filipe, foram capturados. Ele havia honrado os princípios da Cavalaria. E agora a França mergulhava no caos.

\section{Conclusão}

João II morreria no cativeiro. O Delfim, atuando como regente, foi forçado a assinar Tratado de Brétigny (1360), que concedia grande parte do território oeste da França aos ingleses. Saqueadores e bandidos assombravam as vilas, camponeses se insurgiam e Carlos de Navarra

${ }^{73}$ The English and Gascons came in such numbers from all sides that they shattered the King's division. The French were so overwhelmed by their enemies that in places there were five men-at-arms attacking a single knight. Sir Geoffroy de Charny was killed, with the banner of France in his hands.

${ }^{74}$ FROISSART, Jean. Chronicles.Trad. Geoffrey Brereton. Baltimore: Penguin Classics, 1968. p. 140.

${ }^{75}$ DRUCIAK, Carmem Lúcia. A Escrita da História na França de 1380 a 1404: As Representações Discursivas sobre o Cavaleiro Bertrand du Guesclin (†1380). 2018. 285 f. Tese (Doutorado em História) - Setor de Ciências Humanas, Programa de PósGraduação em História, Universidade Federal do Paraná, Curitiba, 2018. p. 259.

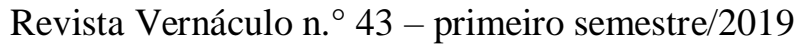

ISSN $2317-4021$ 
almejava coroa. Carlos V, coroado em 1364, após a morte de seu pai, receberia um reino em frangalhos ${ }^{76}$.

Maurice Keen, falecido medievalista britânico da Universidade de Oxford e o grande referencial da pesquisa contemporânea sobre Cavalaria, considera como elemento definidor da mesma o ethos cavaleiresco, tido como um modo de vida marcado por um conjunto de costumes e valores, especialmente o código de conduta guerreiro que valoriza a proeza, a honra e a reputação acima de tudo ${ }^{77}$. Neste sentido, a Cavalaria sobreviveria ao século XIV e permaneceria na retórica aristocrática durante o século $\mathrm{XV}^{78}$, sendo elemento crucial no debate político da Guerra das Rosas.

$\mathrm{Na}$ Inglaterra, Eduardo III se tornaria a imagem ideal do reicavaleiro, diante da qual seus sucessores seriam mensurados. Sua reputação só era superada pela de seu filho que, no entanto, não chegaria a ser rei. Seu neto, Ricardo II, após um reinado conturbado, foi deposto. De acordo com Saul: "O usurpador de Ricardo, Henrique IV, que havia sido cruzado, mais do que estava à altura das expectativas dos seus súditos. Ele era tudo que Ricardo, avesso à guerra, não era. Ele

${ }^{76}$ SUMPTION, Jonathan. The Hundred Years War v. II: Trial by Fire. Philadelphia: University of Pennsylvania Press, 1999. p. 511-512.

77 KEEN, Maurice. Chivalry.New Haven; London: Yale University Press, 1984. passim.

${ }^{78}$ BARKER, Juliet. Agincourt. Rio de Janeiro: Record, 2009. passim.

Revista Vernáculo n. ${ }^{\circ} 43$ - primeiro semestre/2019

ISSN 2317-4021 
representava os mais elevados ideais cavaleirescos da época",7980.A conexão entre política e Cavalaria mais uma vez se manifestava.

Enquanto os valores cavaleirescos seriam defendidos com grande veemência até o século XVI, principalmente através dos torneios $^{81}$, a Cavalaria se retiraria cada vez mais dos campos de batalha. À medida que a Guerra dos Cem Anos progredia, homens-de-armas sem aspiração de se tornarem cavaleiros tornavam-se cada vez mais comuns. Eram soldados profissionais que guerreavam por soldo, pouco se importando com o código de conduta aristocrático. Os duques e condes saíam das linhas de frente e assumiam posições de comando. A "Cavalaria" tornava-se "cavalaria".

A França terminaria por vencer a guerra. Para tanto seria necessária uma profunda reforma militar no século XV, com a criação de um exército permante, além da liderança inspiradora de Joana D'Arc, que resgataria seu ânimo combalido. Mas houve outro fator fundamental: o desenvolvimento de uma poderosa artilharia, cuja utilização lhes daria o triunfo final sobre os ingleses em Castillon (1453).

O desenvolvimento das armas-de-fogo marcaria o fim de uma era. Nas palavras de Clifford J. Rogers: "E assim a 'Idade Média'

${ }^{79}$ Richard's supplanter, Henry IV, a one-time crusader, more than measured up to the expectations of his subjects. He was everything that the unwarlike Richard was not. He stood for the highest chivalric ideals of the day.

${ }^{80}$ SAUL, Nigel. Chivalry in Medieval England. Cambridge: Harvard University Press, 2011.p. 114.

${ }^{81}$ BASCHET, Jérôme. A Civilização Feudal: Do Ano Mil à Conquista da América. São Paulo: Globo, 2006.p. 255.

Revista Vernáculo n. ${ }^{\circ} 43$ - primeiro semestre/2019

ISSN 2317-4021 
chegava ao seu fim, com espessas nuvens de fumaça de pólvora como sua cortina final ${ }^{\prime \prime 283}$.

\section{Referências}

AUTRAND, Françoise. The Battle of Crécy: A Hard Blow for the Monarchy of France. In: AYTON, Andrew; PRESTON, Philip. The Battle of Crécy, 1346. Woodbridge: The Boydel Press, 2007.

AYTON, Andrew. The Battle of Crécy: Context and Significance. In: ; PRESTON, Philip. The Battle of Crécy, 1346. Woodbridge: The Boydel Press, 2007.

BARKER, Juliet. Agincourt. Rio de Janeiro: Record, 2009.

BASCHET, Jérôme. A Civilização Feudal: Do Ano Mil à Conquista da América. São Paulo: Globo, 2006.

BOULTON, D'Arcy J. D. Knights of the Crown: The Monarchical Orders of Knighthood in Later Medieval Europe, 13251520.Woodbrige, TheBoydel Press, 1987.

BRAGANÇA JÚNIOR, Álvaro. A Cavalaria na Idade Média: Entre a Guerra e a Civilização. In: ZIERER, Adriana; . Cavalaria e Nobreza: Entre a História e a Literatura. Maringá: Eduem, 2017. p. 2545 .

CHARNY, Geoffroi de.A Knight's Own Book of Chivalry. Trad. Elspeth Kennedy. Philadelphia: University of Pennsylvania Press, 2005.

${ }^{82}$ Thus did the 'middle ages' draw to their close, with thick clouds of black-powder smoke as their final curtain.

${ }^{83}$ ROGERS, Clifford J. The Age of The Hundred Years War. In: KEEN, Maurice (ed.). Medieval Warfare: A History. Oxford: Oxford University Press, 1999. p. 136160.p. 160.

Revista Vernáculo n. ${ }^{\circ} 43$ - primeiro semestre/2019

ISSN 2317-4021 
CONTAMINE, Philippe. War in the Middle Ages. New York: Barnes \& Noble, 1998.

DRUCIAK, Carmem Lúcia. A Escrita da História na França de 1380 a 1404: As Representações Discursivas sobre o Cavaleiro Bertrand du Guesclin (†1380). 2018. 285 f. Tese (Doutorado em História) - Setor de Ciências Humanas, Programa de Pós-Graduação em História, Universidade Federal do Paraná, Curitiba, 2018.

FLORI, Jean. A Cavalaria. São Paulo: Madras, 2005.

FRANCO JÚNIOR, Hiláro. A Idade Média: O Nascimento do Ocidente. 2 ed. rev. e ampl. São Paulo: Brasiliense, 2001.

FROISSART, Jean. Chronicles. Trad. Geoffrey Brereton. Baltimore: Penguin Classics, 1968.

GARCÍA FITZ, Francisco. Ejércitos y Actividades Guerreras en la Edad Media Europea. Madri: Arco Libros, 1998.

KAEUPER, Richard W. Chivalry and Violence in Medieval Europe. Oxford: Oxford University Press, 1999.

. Historical Introduction to the Text. In: CHARNY, Geoffroi de. A Knight's Own Book of Chivalry. Trad. Elspeth Kennedy. Philadelphia: University of Pennsylvania Press, 2005.

KEEN, Maurice. Chivalry. New Haven; London: Yale University Press, 1984.

LE GOFF, Jacques. Heróis e Maravilhas da Idade Média.2 ed. Petrópolis: Vozes, 2011.

ROGERS, Clifford J. The Age of The Hundred Years War. In: KEEN, Maurice (ed.). Medieval Warfare: A History. Oxford: Oxford University Press, 1999. p. 136-160.

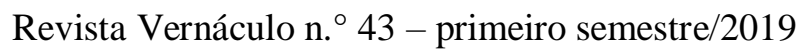

ISSN 2317-4021 
. The Military Revolutions of the Hundred Years' War. The Journal of Military History, Lexington, v. 57, p. 1-33, 1993. Disponívelem: $<$ http://deremilitari.org/2014/06/the-militaryrevolutions-of-the-hundred-years-war/>. Acesso em: $20 \mathrm{dez} .2018$.

SACCOMORI, Guilherme Floriani. Guerreiros e Batalhas na Mira de Jean Froissart (1337-1405): Cenário em Transformação. 2015. $121 \mathrm{f}$. Dissertação (Mestrado em História) - Setor de Ciências Humanas, Programa de Pós-Graduação em História, Universidade Federal do Paraná, Curitiba, 2015.

SAUL, Nigel. Chivalry in Medieval England. Cambridge: Harvard University Press, 2011.

SUMPTION, Jonathan. The Hundred Years War v. I: Trial by Battle. Philadelphia: University of Pennsylvania Press, 1990.

. The Hundred Years War v. II: Trial by Fire. Philadelphia: University of Pennsylvania Press, 1999.

WAGNER, John A. Encyclopedia of the Hundred Years War. Westport: Greenwood Press, 2006.

Recebido em 17/08/18 aceito para publicação em 27/12 /18

Revista Vernáculo n. ${ }^{\circ} 43$ - primeiro semestre/2019

ISSN 2317-4021 